\title{
Peranan Pemerintah Daerah Dalam Upaya Perlindungan Pra Penempatan Pekerja Migran Indonesia Di Luar Negeri
}

\author{
Sonhaji \\ Fakultas Hukum, Universitas Diponegoro \\ J1. Prof. Soedarto, SH Tembalang Semarang \\ E-mail : sonhajimuh19@gmail.com
}

\begin{abstract}
Abstrak
Penelitian dengan judul peranan Dinas Perindustrian dan Tenaga Kerja Kabupaten Purworejo dalam upaya perlindungan pra penempatan pekerja migran Indonesia di luar negeri ini bertujuan untuk mengetahui peran Dinas Perindustrian dan Tenaga Kerja Kabupaten Purworejo dalam upaya perlindungan pra penempatan pekerja migran Indonesia di luar negeri, untuk mengetahui hambatan yang dialami, serta untuk mengetahui upaya yang dilakukan dalam mengatasi hambatan tersebut. Hasil penelitian menunjukkan bahwa peran Dinas Perindustrian dan Tenaga Kerja Kabupaten Purworejo dalam upaya perlindungan pra penempatan pekerja migran Indonesia di luar negeri adalah sudah sesuai dengan aturan yang berlaku. Walaupun dalam pelaksanaan perannya mengalami beberapa hambatan yang mana hambatan tersebut berasal dari pekerja migran Indonesia yang bersangkutan. Dinas Perindustrian dan Tenaga Kerja Kabupaten Purworejo melakukan upaya-upaya dalam mengatasi hambatan yang timbul pada saat melaksanakan perannya sehingga pelaksanaan perannya dapat berjalan dengan lancar.
\end{abstract}

Kata Kunci: Peranan Pemerintah Daerah, Perlindungan Prapenempatan Pekerja Migran Indonesia di Luar Negeri

\begin{abstract}
Research from the role of the Department of Industry and Manpower in Purworejo Regency in an effort to protect the pre-placement of Indonesian migrant workers abroad aims to find out the role of the Department of Industry and Manpower in Purworejo Regency in an effort to protect pre-placement of Indonesian migrant workers abroad, to find out the obstacles experienced, and to find out the efforts made in overcoming these obstacles. The results of the study indicate that the role of the Department of Industry and Labor Purworejo Regency in an effort to protect the pre-placement of Indonesian migrant workers abroad is in accordance with applicable regulations. Although in the implementation of its role there have been several obstacles which these obstacles come from the Indonesian migrant workers in question. The Department of Industry and Manpower of Purworejo Regency makes efforts in overcoming the obstacles that arise when carrying out its role so that the implementation of its role can run smoothly.
\end{abstract}

Keywords: Role of Local Government, Pre Protection of Placement of Indonesian Migrant Workers Abroad

\section{A. Pendahuluan}

Tekanan yang baru-baru ini diberikan pada pendekatan kebutuhan dasar dalam perencanaan pembangunan, mencerminkan kekecewaan terhadap strategi-strategi 
pembangunan di masa lampau, yang sebagian besar gagal dalam mengurangi, apalagi menghapus kemiskinan di kebanyakan negara berkembang. Sekalipun selama dua dasawarsa yang baru lalu negara-negara berkembang sebagai satu kelompok telah mengalami pertumbuhan ekonomi yang pesat, malahan lebih pesat daripada yang pernah dialami oleh negara-negara industri Barat selama tahap-tahap permulaan dari proses industrialisasi mereka, namun pertumbuhan ekonomi pesat ini pada umumnya ternyata tidak terlalu berhasil dalam menyediakan kesempatan kerja yang produktif bagi penduduk yang bertambah secara pesat di negara-negara ini maupun dalam mengurangi secara berarti kemiskinan yang tersebar luas di negara-negara tersebut.

Kegagalan kebijakan konvensional mengenai pertumbuhan ekonomi di berbagai negara berkembang, dalam mengurangi kemiskinan, pengangguran, dan disparitas (ketimpangan) pendapatan secara berarti, telah memaksa para perencana ekonomi dan pembangunan nasional untuk kembali mempelajari dengan sungguh-sungguh kebijakan-kebijakan yang telah ada, serta mendorongnya untuk mempelajari alternatifalternatif yang lebih realistis bagi kebijaksanaan pertumbuhan ekonomi yang konvensional. ${ }^{1}$

Pembangunan nasional yang dilaksanakan selama ini pada hakekatnya merupakan suatu usaha untuk mewujudkan cita-cita bangsa Indonesia. Subyek dari pembangunan nasional tersebut adalah tenaga kerja. Tenaga kerja adalah pelaku untuk mencapai tujuan pembangunan nasional. ${ }^{2}$ Selain itu, pembangunan nasional juga merupakan rangkaian upaya pembangunan yang berkesinambungan yang meliputi seluruh kehidupan masyarakat, bangsa, dan negara untuk melaksanakan tugas mewujudkan tujuan nasional yang tertuang dalam Pembukaan Undang-Undang Dasar Tahun 1945.

Bangsa Indonesia sejak negara ini didirikan, telah menyadari bahwa pekerjaan merupakan kebutuhan asasi warga negara sebagaimana diamanatkan dalam Pasal 27 ayat (2) Undang-Undang Dasar Tahun 1945 yang menyatakan bahwa tiap-tiap warga

\footnotetext{
${ }^{1}$ ILO, Employment, Growth, and Basic Needs: A One-World Problem-Report of the Director General of ILO to the Tripartit World Employment Conference, Geneve

${ }^{2}$ Sonhaji, Aspek Hukum Penyerahan Sebagian Pekerjaan Kepada Perusahaan Lainnya, Adminitrative Law \& Governance Journal Vol. 1, Edisi 2 Mei 2018, hlm 16
} 
negara berhak atas pekerjaan dan penghidupan yang layak bagi kemanusiaan. Amandemen Undang-Undang Dasar Tahun 1945 tentang ketenagakerjaan juga menyebutkan dalam Pasal 28D ayat (2) Undang-Undang Dasar Tahun 1945. Hal tersebut mendorong negara untuk menjalankan kewajibannya dengan cara memberikan fasilitas-fasilitas kepada warga negaranya supaya memperoleh pekerjaan yang layak bagi kemanusiaan. Oleh karena itu, diperlukan perencanaan yang matang di bidang ketenagakerjaan untuk mewujudkan kewajiban negara tersebut.

Pertumbuhan penduduk yang tinggi dan penyebaran penduduk yang kurang seimbang, merupakan faktor yang amat mempengaruhi tentang masalah ketenagakerjaan di tanah air kita. ${ }^{3}$ Masalah ketenagakerjaan merupakan bagian yang tidak terpisahkan dari masalah ekonomi, sehingga masalah masalah pembangunan ketenagakerjaan juga merupakan bagian dari pembangunan ekonomi. Dengan demikian, perencanaan ekonomi harus mencakup juga perencanaan ketenagakerjaan.

Kondisi perekonomian Indonesia sebagaimana dampak dari adanya globalisasi secara langsung dapat dirasakan oleh bangsa Indonesia di mana krisis ekonomi yang melanda negeri ini pada akhir 1997 mengakibatkan jumlah pekerja migran Indonesia ke luar negeri meningkat tajam. Penyebab dari kondisi demikian ini adalah lapangan pekerjaan yang tersedia di dalam negeri semakin sempit sehingga memaksa banyak warga negara Indonesia untuk bekerja sebagai tenaga kerja ke luar negeri.

Masalah pekerja migran Indonesia masih mewarnai kondisi ketenagakerjaan Indonesia yang seakan-akan tidak pernah berhenti mengalir. Pekerja migran Indonesia dalam kenyataan yang terjadi, yang bekerja di luar negeri kadang-kadang menghadapi berbagai persoalan, antara lain menjadi obyek perdagangan manusia, termasuk perbudakan dan kerja paksa, korban kekerasan, kesewenang-wenangan, kejahatan atas harkat dan martabat manusia, hak pada pekerja wanita tidak diberikan, penempatan lokasi kerja tidak sesuai dengan awal perjanjian, mendapat hukuman dari pemerintah setempat, perlakuan diskriminasi, serta perlakuan lain yang melanggar hak asasi

\footnotetext{
${ }^{3}$ Suhartoyo, Penguatan Organisasi Buruh / Pekerja Sebagai Sarana Perlindungan Buruh,Administrative Law \& Governance Journal Vol. 1, Edisi 4 November 2018, hlm 351-352
} 


\section{Administrative Law \& Governance Journal. Volume 2 Issue 1, March 2020 ISSN. 2621-2781 Online}

manusia. Bahkan seperti permasalahan yang menimpa pekerja migran Indonesia asal Kabupaten Purworejo yakni sebanyak 37 orang di tahan di Malaysia. Mereka dicurigai sebagai tenaga kerja illegal. Namun, pihak penyalur pekerja migran Indonesia menegaskan bahwa 37 pekerja migran Indonesia tersebut telah memenuhi persyaratan secara administrasi. Dengan kata lain, hal tersebut tidak disebabkan karena syarat-syarat legalitas yang belum lengkap. Akan tetapi penahanan tersebut disebabkan karena adanya kesalahan dalam penempatan pekerja migran Indonesia. ${ }^{4}$

Permasalahan pekerja migran Indonesia seperti tersebut di atas yang tidak ada akhirnya sangat memerlukan upaya, solusi, tindakan, serta kebijakan responsif dari pemerintah, terutama pemerintah daerah khususnya Kabupaten Purworejo supaya masalah-masalah yang tengah dihadapi pekerja migran Indonesia yang berasal dari Kabupaten Purworejo dapat menemukan jalan keluar.

Dari uraian di atas maka, permasalahan yang dapat disusun antara lain: Bagaimana peran Dinas Perindustrian dan Tenaga Kerja Kabupaten Purworejo dalam upaya perlindungan pra penempatan pekerja migran Indonesia di luar negeri ? Bagaimana hambatan yang dialami Dinas Perindustrian dan Tenaga Kerja Kabupaten Purworejo dalam upaya perlindungan pra penempatan pekerja migran Indonesia di luar negeri ? Bagaimana upaya Dinas Perindustrian dan Tenaga Kerja Kabupaten Purworejo dalam mengatasi hambatan tersebut?

\section{B. Metode Penelitian}

Metode pendekatan yang digunakan dalam penelitian ini adalah pendekatan yuridis empiris. Pendekatan yuridis dimana hukum dilihat sebagai norma atau das sollen, karena dalam membahas permasalahan penelitian ini menggunakan bahan-bahan hukum (baik hukum yang tertulis maupun hukum yang tidak tertulis atau baik bahan hukum primer maupun bahan hukum sekunder). Sedangkan pendekatan empiris, dimana hukum sebagai kenyataan sosial, kultural atau das sein, karena dalam penelitian

\footnotetext{
${ }^{4}$ https://news.detik.com/berita-jawa-tengah/d-3857207/dokumen-dipersoalkan-37-tki-asal-purworejo-ditahandi-malaysia diakses pada 14 Maret 2019 pukul 20.18
} 


\section{Administrative Law \& Governance Journal. Volume 2 Issue 1, March 2020 ISSN. 2621-2781 Online}

ini digunakan data primer yang diperoleh dari lapangan. Dengan demikian, Yuridis empiris adalah pendekatan yang dilakukan dengan cara menggali informasi dan melakukan penelitian di lapangan guna mengetahui secara lebih jauh mengenai permasalahan yang dibahas. Peneliti dalam menganalisa masalah yang ada berdasarkan peraturan perundang-undangan, prinsip-prinsip, teori-teori, dan azaz-azaz hukum yang berlaku dengan bantuan ilmu sosial yang lain. Manfaat yang diperoleh adalah mengetahui dan mendapatkan data mengenai bagaimana peran Dinas Perindustrian dan Tenaga Kerja Kabupaten Purworejo dalam upaya perlindungan pra penempatan pekerja migran Indonesia di luar negeri, mengetahui hambatan yang dialami, serta mengetahui upaya yang dilakukan dalam mengatasi hambatan tersebut.

Spesifikasi penelitian yang digunakan dalam penelitian ini adalah secara deskriptif analitis. Deskriptif, yaitu penelitian yang bertujuan melukiskan tentang suatu hal di daerah tertentu dan pada saat tertentu..$^{5}$ Analitis, maksudnya dikaitkan dengan teoriteori hukum yang ada dan atau peraturan perundang-undangan yang berkaitan dengan obyek yang diteliti. Dengan adanya objek penelitian dan didukung oleh data-data yang berkaitan dengan perlindungan pra penempatan pekerja migran Indonesia di luar negeri yang akan diungkapkan diharapkan akan memberikan penjelasan secara cermat dan menyeluruh serta sistematis.

Metode penentuan sampel yang digunakan dalam penelitian ini adalah purposive sampling. Purposive sampling adalah pemilihan sekelompok subyek atas ciri-ciri atau sifat-sifat tertentu yang dipandang mempunyai sangkut paut yang erat dengan ciri-ciri atau sifat-sifat populasi yang sudah diketahui sebelumnya. ${ }^{6}$ Penelitian ini menggunakan teknik purposive sampling, karena peneliti merasa sampel yang diambil mengetahui tentang permasalahan yang akan diteliti.

Jenis dan sumber data dalam penelitian ini dikelompokkan menjadi dua yaitu data primer dan data sekunder. Data primer adalah data yang diperoleh seorang peneliti

\footnotetext{
${ }^{5}$ Ronny Hanitijo Soemitro, Metodologi Penelitian Hukum dan Jurimetri, (Jakarta: Ghalia Indonesia, 1982), hlm 35

${ }^{6}$ Ronny Hanitijo Soemitro, Metodologi Penelitian Hukum dan Jurimetri, (Jakarta: Ghalia Indonesia, 1990), hlm 51
} 


\section{Administrative Law \& Governance Journal. Volume 2 Issue 1, March 2020 ISSN. 2621-2781 Online}

langsung dari sumbernya tanpa perantara pihak lain (langsung dari objeknya), lalu dikumpulkan dan diolah sendiri atau seorang atau suatu organisasi. ${ }^{7}$ Dalam penelitian hukum ini, data primer diperoleh dari proses wawancara yang dilakukan dengan aparatur Dinas Perindustrian dan Tenaga Kerja Kabupaten Purworejo yaitu Trimo, Yacobus Alex Yocom, dan Pranoto Puji Hidayanto dan dari PT Dian Yogya Perdana Cabang Purworejo selaku Perusahaan Penempatan Pekerja Migran Indonesia di Kabupaten Purworejo adalah Tri Marzuningsih dan Yuzman Faezal, serta kepada Januarti Ramdhani selaku pekerja migran Indonesia. Sedangkan data sekunder adalah data yang bersumber dari penelitian kepustakaan.

Metode pengumpulan data dalam penelitian ini menggunakan studi kepustakaan dan studi lapangan dimana studi kepustakaan yaitu mengumpulkan data yang dilakukan dengan cara membaca, mengutip, mencatat dan memahami berbagai literatur yang ada hubungannya dengan peran Dinas Perindustrian dan Tenaga Kerja Kabupaten Purworejo dalam upaya perlindungan pra penempatan pekerja migran Indonesia di luar negeri. Sedangkan studi lapangan yaitu mengumpulkan data yang mengadakan penelitian langsung pada tempat atau objek penelitian yang dilakukan dengan wawancara kepada para informan yang sudah ditentukan yaitu Trimo, Yacobus Alex Yocom, dan Pranoto Puji Hidayanto selaku aparatur dari Dinas Perindustrian dan Tenaga Kerja Kabupaten Purworejo serta kepada Tri Marzuningsih dan Yuzman Faezal selaku pihak dari PT Dian Yogya Perdana Cabang Purworejo yang bergerak di bidang Perusahaan Penempatan Pekerja Migran Indonesia di Kabupaten Purworejo, dan juga kepada Januarti Ramdhani selaku pekerja migran Indonesia.

Penulisan hukum ini menggunakan analisis kualitatif. Analisis kualitatif yaitu suatu analisis penelitian yang dilakukan dengan cara memahami dan menggunakan data-data yang telah dikumpulkan secara sistematis sehingga mendapat suatu gambaran mengenai kenyataan yang berlaku dan masih ada kaitannya dengan ketentuan hukum yang berlaku serta proses penalaran dalam menarik kesimpulan digunakan metode berpikir induktif,

\footnotetext{
${ }^{7}$ Suteki dan Galang Taufani, Metodologi Penelitian Hukum (Filsafat, Teori dan Praktik), Cetakan ke-1, (Depok: PT RajaGrafindo Persada, 2018), hlm 214
} 
yaitu metode yang berangkat pada pengetahuan-pengetahuan yang bersifat khusus untuk digunakan dalam menarik kesimpulan atas suatu kejadian atau peristiwa yang bersifat umum. ${ }^{8}$

Data yang telah dikumpulkan dalam penelitian ini kemudian akan digabungkan untuk diolah lebih lanjut. Dalam proses ini akan diadakan suatu editing, yaitu kegiatan memeriksa atau meneliti data yang telah diperoleh untuk menjamin apakah sudah dapat dipertanggungjawabkan sesuai kenyataan. Selanjutnya dalam editing dilakukan pembetulan data yang keliru, menambah data yang kurang, dan melengkapi data yang belum lengkap. ${ }^{9}$

\section{A. Hasil Penelitian}

Peran Dinas Perindustrian dan Tenaga Kerja Kabupaten Purworejo dalam Upaya Perlindungan Pra Penemptana Pekerja Migran Indonesia di Luar Negeri

Dinas Perindustrian dan Tenaga Kerja merupakan salah satu lembaga pemerintahan yang terletak di Kabupaten Purworejo. Dinas tersebut memiliki peran sebagai penyelenggara urusan Pemerintah Daerah Kabupaten Purworejo, khususnya di Bidang Ketenagakerjaan. Berkaitan dengan peran dalam upaya perlindungan pra penempatan pekerja migran Indonesia, Trimo menjelaskan bahwa Dinas Perindustrian dan Tenaga Kerja mengadakan sosialisasi atau memberikan penjelasan mengenai proses ke luar negeri yang sesuai dengan prosedur. Sosialisasi tersebut dilakukan di sekolah, di kantor, serta di tingkat kecamatan. Pada tahun 2018, Dinas Perindustrian dan Tenaga Kerja mengadakan sosialisasi di lima kecamatan yaitu Kecamatan Bagelen, Kecamatan Purwodadi, Kecamatan Ngombol, Kecamatan Kemiri, dan Kecamatan Kutoarjo dimana setiap kecamatan diikuti oleh 50 orang. Target sosialisasi tersebut adalah tokoh masyarakat dan kepala desa. Pada sesi sosialisasi, Dinas Perindustrian dan Tenaga Kerja

${ }^{8}$ Sutrisno Hadi, Metodologi Research, UGM, hlm 36 ${ }^{9}$ Ronny Hanitijo Soemitro, Op.Cit., hlm 64 
memberikan informasi dengan narasumber dari kepolisian, Imigrasi Wonosobo, dan Pelaksana Penempatan Pekerja Migran Indonesia (P3MI) Berkah Makmur. Dari langkah tersebut, Dinas Perindustrian dan Tenaga Kerja memberikan solusi tentang prosedur penempatan tenaga kerja ke luar negeri untuk bekerja secara benar atau legal, dari kepolisian memberikan materi tentang perdagangan manusia, Imigrasi Wonosobo memberikan materi tentang paspor, dan Pelaksana Penempatan Pekerja Migran Indonesia (P3MI) Berkah Makmur memberikan materi tentang prosedur penempatan pekerjanya. ${ }^{10}$

Metode sosialisasi menurut Yakobus Alex Yocom, dalam penyuluhan dan penyebarluasan informasi pasar kerja yang dihadiri oleh perangkat desa yang telah diundang, maka nantinya perangkat desa tersebut yang akan menyampaikan kepada warganya. Mengenai dokumen yang harus dilengkapi untuk bekerja ke luar negeri adalah seperti yang tercantum dalam Pasal 13 Undang-Undang Nomor 18 Tahun 2017 tentang Pelindungan Pekerja Migran Indonesia antara lain: ${ }^{11}$

a. Surat keterangan status perkawinan, bagi yang telah menikah melampirkan fotokopi buku nikah;

b. Surat keterangan izin suami atau istri, izin orang tua, atau wali yang diketahui oleh kepala desa atau lurah;

c. Sertifikat kompetensi kerja;

d. Surat keterangan sehat berdasarkan hasil pemeriksaan kesehatan dan psikologi;

e. Paspor yang diterbitkan oleh kantor imigrasi setempat;

f. Visa kerja;

g. Perjanjian penempatan pekerja migran Indonesia; dan

h. Perjanjian kerja.

Dari berbagai dokumen tersebut, maka terkait dengan surat izin orang tua atau wali harus disyahkan oleh kepala desa atau lurah. Dengan demikian, kepala desa atau

\footnotetext{
${ }^{10}$ Trimo, S.E., Wawancara, Kepala Seksi Penempatan dan Perluasan Tenaga Kerja Dinas Perindustrian dan Tenaga Kerja, Purworejo 11 Februari 2019

${ }^{11}$ Yakobus Alex Yocom, Wawancara, Pelaksana Bidang Penempatan dan Perluasan Tenaga Kerja Dinas Perindustrian dan Tenaga Kerja, Purworejo 20 Februari 2019
} 
lurah tersebut dalam memberikan pengantar atau legalitas biasanya meminta surat permohonan ke Dinas Perindustrian dan Tenaga Kerja dari perusahaan jasa tenaga kerja Indonesia (PJTKI)nya. Jadi, disini dapat terlihat bahwa pemrosesan pekerja migran Indonesia tersebut resmi atau tidak dari pihak perusahaan jasa tenaga kerja Indonesia (PJTKI). ${ }^{12}$

Peran Dinas Perindustrian dan Tenaga Kerja tidak terbatas pada sosialisasi saja. Akan tetapi Dinas Perindustrian dan Tenaga Kerja juga membuat rekomendasi paspor untuk pekerja migran Indonesia. Dalam penempatan tenaga kerja sudah berbasis online yakni melalui sistem komputerisasi tenaga kerja luar negeri (SISKOTKLN). Data-data yang termuat dalam sistem komputerisasi tenaga kerja luar negeri (SISKOTKLN) adalah mengenai rekomendasi paspor, nomor identitas diri pekerja migran Indonesia, data diri pekerja migran Indonesia, dan berita acara penempatan. Dengan adanya sistem online ini, maka Dinas Perindustrian dan Tenaga Kerja untuk memperbarui data terkoneksi dengan Dinas Kependudukan dan Pencatatan Sipil, Dinas Tenaga Kerja dan Transmigrasi Provinsi, Imigrasi, dan Kementerian Ketenagakerjaan / Badan Nasional Penempatan dan Perlindungan Tenaga Kerja Indonesia (BNP2TKI). ${ }^{13}$

Pranoto Puji Hidayanto menambahkan bahwa peran Dinas Perindustrian dan Tenaga Kerja dalam upaya perlindungan pra penempatan pekerja migran Indonesia adalah Dinas melakukan proses wawancara kepada calon pekerja migran Indonesia sebelum melakukan penerbitan identitas diri calon pekerja migran Indonesia. Dari wawancara, Dinas Perindustrian dan Tenaga Kerja dapat melihat keabsahan dokumennya seperti Kartu Tanda Penduduk, Kartu Keluarga, akta kelahiran, ijazah, surat izin orang tua, dan surat nikah bagi yang sudah menikah. Dokumen-dokumen tersebut kemudian diverifikasi yang kemudian dilanjutkan dengan proses wawancara. Beberapa hal yang ditanyakan dalam proses wawancara adalah

\footnotetext{
${ }^{12} \mathrm{Op}$., Cit

${ }^{13}$ Trimo, S.E., Wawancara, Kepala Seksi Penempatan dan Perluasan Tenaga Kerja Dinas Perindustrian dan Tenaga Kerja, Purworejo 11 Februari 2019
} 
mengenai perusahaan pengguna, gaji pokok, kontrak kerja, fasilitas yang didapat, dan biaya proses. Selain itu, peran Dinas Perindustrian dan Tenaga Kerja adalah menjelaskan hak dan kewajiban calon pekerja migran Indonesia/pekerja migran Indonesia sesuai dengan surat perjanjian penempatan. ${ }^{14}$ Hak dan kewajiban calon pekerja migran Indonesia/pekerja migran Indonesiadalam surat perjanjian penempatan adalah seperti yang tercantum dalam Pasal 6 ayat (1) dan Pasal 6 ayat (2) Undang-Undang Nomor 18 Tahun 2017 tentang Pelindungan Pekerja Migran Indonesia. Adapun hak dan kewajiban calon pekerja migran Indonesia/pekerja migran Indonesia sesuai dengan Undang-Undang Nomor 18 Tahun 2017 tentang Pelindungan Pekerja Migran Indonesia antara lain: ${ }^{15}$

Pasal 6 ayat (1)

Setiap calon pekerja migran Indonesia atau pekerja migran Indonesia memiliki hak:

a. Mendapatkan pekerjaan di luar negeri dan memilih pekerjaan sesuai dengan kompetensinya;

b. Memperoleh akses peningkatan kapasitas diri melalui pendidikan dan pelatihan kerja;

c. Memperoleh informasi yang benar mengenai pasar kerja, tata cara penempatan, dan kondisi kerja di luar negeri;

d. Memperoleh pelayanan yang profesional dan manusiawi serta perlakuan tanpa diskriminasi pada saat sebelum bekerja, selama bekerja, dan setelah bekerja;

e. Menjalankan ibadah sesuai dengan agama dan keyakinan yang dianut;

f. Memperoleh upah sesuai dengan standar upah yang berlaku di negara tujuan penempatan dan/atau kesepakatan kedua negara dan/atau Perjanjian Kerja;

g. Memperoleh pelindungan dan bantuan hukum atas tindakan yang dapat merendahkan harkat dan martabat sesuai dengan ketentuan peraturan perundang-undangan di Indonesia dan di negara tujuan penempatan;

\footnotetext{
${ }^{14}$ Pranoto Puji Hidayanto, Wawancara, Pelaksana Bidang Penempatan dan Perluasan Tenaga Kerja Dinas Perindustrian dan Tenaga Kerja, Purworejo 13 Februari 2019

${ }^{15}$ Yakobus Alex Yocom, Wawancara, Pelaksana Bidang Penempatan dan Perluasan Tenaga Kerja Dinas Perindustrian dan Tenaga Kerja, Purworejo 20 Februari 2019
} 


\section{Administrative Law \& Governance Journal. Volume 2 Issue 1, March 2020 ISSN. 2621-2781 Online}

h. Memperoleh penjelasan mengenai hak dan kewajiban sebagaimana tertuang dalam Perjanjian Kerja;

i. Memperoleh akses berkomunikasi;

j. Menguasai dokumen perjalanan selama bekerja;

k. Berserikat dan berkumpul di negara tujuan penempatan sesuai dengan ketentuan peraturan perundang-undangan yang berlaku di negara tujuan penempatan;

1. Memperoleh jaminan pelindungan keselamatan dan keamanan kepulangan pekerja migran Indonesia ke daerah asal; dan/atau

m. Memperoleh dokumen dan Perjanjian Kerja Calon Pekerja Migran Indonesia dan/atau Pekerja Migran Indonesia.

Pasal 6 ayat (2)

Setiap pekerja migran Indonesia memiliki kewajiban:

a. Menaati peraturan perundang-undangan, baik di dalam negeri maupun di negara tujuan penempatan;

b. Menghormati adat-istiadat atau kebiasaan yang berlaku di negara tujuan penempatan;

c. Menaati dan melaksanakan pekerjaannya sesuai dengan Perjanjian Kerja; dan

d. Melaporkan kedatangan, keberadaan, dan kepulangan pekerja migran lndonesia kepada Perwakilan Republik Indonesia di negara tujuan penempatan.

Kewenangan Dinas Perindustrian dan Tenaga Kerja sesuai dengan yang tercantum dalam Undang-Undang Nomor 18 Tahun 2017 tentang Pelindungan Pekerja Migran Indonesia adalah Dinas Perindustrian dan Tenaga Kerja berhak memberikan perlindungan pra penempatan (pelindungan sebelum bekerja), saat penempatan (pelindungan selama bekerja), hingga kepulangan pekerja migran Indonesia ke tanah air (pelindungan setelah bekerja). Pelindungan sebelum bekerja adalah keseluruhan aktivitas untuk memberikan pelindungan sejak pendaftaran sampai pemberangkatan, pelindungan selama bekerja adalah keseluruhan aktivitas untuk memberikan pelindungan selama pekerja migran Indonesia dan anggota keluarganya berada di luar negeri, dan pelindungan setelah bekerja adalah 
keseluruhan aktivitas untuk memberikan pelindungan sejak pekerja migran Indonesia dan anggota keluarganya tiba di debarkasi di Indonesia hingga kembali ke daerah asal, termasuk pelayanan lanjutan menjadi pekerja produktif. ${ }^{16}$

Terkait dengan permasalahan penahanan 37 pekerja migran Indonesia asal Kabupaten Purworejo, Dinas Perindustrian dan Tenaga Kerja Kabupaten Purworejo akan memfasilitasi untuk membantu menemukan jalan keluar. Seperti yang dijelaskan oleh Yakobus Alex Yocom bahwa yang menjadi masalah adalah izin tempat tinggalnya. Untuk menyelamatkan pekerja migran Indonesia tersebut, Dinas Perindustrian dan Tenaga Kerja Kabupaten Purworejo akan berkoordinasi dengan pelaksana penempatan pekerja migran Indonesia (P3MI) selaku PT yang memproses pekerja migran Indonesia ke luar negeri serta berkoordinasi dengan Kedutaan Besar Republik Indonesia di negara tersebut bersama dengan Kementerian Luar Negeri. Untuk menindaklanjuti masalah tersebut, Dinas Perindustrian dan Tenaga Kerja Kabupaten Purworejo bernegosiasi dengan Balai Pelayanan Penempatan dan Perlindungan Tenaga Kerja Indonesia (BP3TKI), Badan Nasional Penempatan dan Perlindungan Tenaga Kerja Indonesia (BNP2TKI), Kedutaan Besar Republik Indonesia, dan Kementerian Luar Negeri yang pada akhirnya sampai pada kata mufakat yaitu sebanyak 37 pekerja migran Indonesia asal Kabupaten Purworejo tersebut dikembalikan ke Indonesia semua. Selama ditahan di Imigrasi, ada kebijakan dari perusahaan penggunanya yaitu selama ditahan pekerja migran Indonesia tersebut tetap mendapat upah. Dalam hal ini Dinas Perindustrian dan Tenaga Kerja Kabupaten Purworejo selalu memantau sejak permasalahan terjadi sampai perkembangan kasus dan bahkan sampai kasusnya selesai. ${ }^{17}$

Bentuk-bentuk perlindungan yang diberikan oleh Dinas Perindustrian dan Tenaga Kerja terhadap pekerja migran Indonesia di luar negeri dalam masa pra

\footnotetext{
${ }^{16}$ Yakobus Alex Yocom dan Pranoto Puji Hidayanto, Wawancara, Pelaksana Bidang Penempatan dan Perluasan Tenaga KerjaDinas Perindustrian dan Tenaga Kerja, Purworejo 20 Februari 2019

${ }^{17}$ Yakobus Alex Yocom, Wawancara, Pelaksana Bidang Penempatan dan Perluasan Tenaga KerjaDinas Perindustrian dan Tenaga Kerja, Purworejo 20 Februari 2019
} 
penempatan adalah Dinas Prindustrian dan Tenaga Kerja memberikan perlindungan dengan melakukan pembinaan terhadap pelaksana penempatan pekerja migran Indonesia (P3MI) agar melakukan kegiatan penempatan sesuai dengan aturan yang berlaku. ${ }^{18}$ Prosedur penempatan pekerja migran Indonesia sesuai dengan aturan yang berlaku adalah: ${ }^{19}$

1. Pihak yang bersangkutan sebagai pencari kerja mendaftar di Dinas Perindustrian dan Tenaga Kerja;

2. Setelah mendaftar di Dinas Perindustrian dan Tenaga Kerja, akan dibukakan sistem komputerisasi tenaga kerja luar negeri (SISKOTKLN) mengenai PT yang masih ada jobnya;

3. Seleksi administratif;

4. Seleksi pengguna;

5. Medikal;

6. Menandatangani surat perjanjian penempatan;

7. Proses pembuatan paspor:

- Jika tenaga kerja adalah non formal, maka tenaga kerja tersebut menunggu visa kerja dirumah.

- Jika tenaga kerja adalah formal, maka tenaga kerja tersebut harus mengikuti pelatihan di Balai Latihan Kerja, baik melalui perusahaan atau balai pemerintahan.

8. Menandatangani perjanjian kerja; dan

9. Proses pemberangkatan.

Dinas Perindustrian dan Tenaga Kerja dalam memberikan perlindungan pra penempatan pekerja migran Indonesia dasar kewenangannya adalah UndangUndang Nomor 18 Tahun 2017 tentang Pelindungan Pekerja Migran Indonesia

\footnotetext{
${ }^{18}$ Pranoto Puji Hidayanto, Wawancara, Pelaksana Bidang Penempatan dan Perluasan Tenaga KerjaDinas Perindustrian dan Tenaga Kerja, Purworejo 13 Februari 2019

${ }^{19}$ Trimo, S.E., Wawancara, Kepala Seksi Penempatan dan Perluasan Tenaga KerjaDinas Perindustrian dan Tenaga Kerja, Purworejo 18 Februari 2019
} 
pada Pasal 11 ayat (2) dan Pasal 41 yang selanjutnya akan diuraikan sebagai berikut: ${ }^{20}$

Pasal 11 ayat (2)

Pemerintah Daerah kabupaten/kota melakukan sosialisasi informasi dan permintaan Pekerja Migran Indonesia sebagaimana dimaksud pada ayat (1) kepada masyarakat dengan melibatkan aparat Pemerintah Desa.

Pasal 41

Pemerintah Daerah kabupaten/kota memiliki tugas dan tanggung jawab:

a. Menyosialisasikan informasi dan permintaan Pekerja Migran Indonesia kepada masyarakat;

b. Membuat basis data Pekerja Migran Indonesia;

c. Melaporkan hasil evaluasi terhadap Perusahaan Penempatan Pekerja Migran Indonesia secara periodik kepada Pemerintah Daerah provinsi;

d. Mengurus kepulangan Pekerja Migran Indonesia dalam hal terjadi peperangan, bencana alam, wabah penyakit, deportasi, dan Pekerja Migran Indonesia bermasalah sesuai dengan kewenangannya;

e. Memberikan Pelindungan Pekerja Migran Indonesia sebelum bekerja dan setelah bekerja di daerah kabupaten/kota yang menjadi tugas dan kewenangannya;

f. Menyelenggarakan pendidikan dan pelatihan kerja kepada Calon Pekerja Migran Indonesia yang dapat bekerja sama dengan lembaga pendidikan dan lembaga pelatihan kerja milik pemerintah dan/atau swasta yang terakreditasi;

g. Melakukan pembinaan dan pengawasan terhadap lembaga pendidikan dan lembaga pelatihan kerja di kabupaten/kota;

h. Melakukan reintegrasi sosial dan ekonomi bagi Pekerja Migran Indonesia dan keluarganya;

${ }^{20}$ Trimo, S.E., Wawancara, Kepala Seksi Penempatan dan Perluasan Tenaga KerjaDinas Perindustrian dan Tenaga Kerja, Purworejo 11 Februari 2019

Administrative Law \& Governance Journal. Volume 3 Issue 1, March 2020 
i. Menyediakan dan memfasilitasi pelatihan Calon Pekerja Migran Indonesia melalui pelatihan vokasi yang anggarannya berasal dari fungsi pendidikan;

j. Mengatur, membina, melaksanakan, dan mengawasi penyelenggaraan penempatan Pekerja Migran Indonesia; dan

k. Dapat membentuk layanan terpadu satu atap penempatan dan Pelindungan Pekerja Migran Indonesia di tingkat kabupaten/kota.

Peran Dinas Perindustrian dan Tenaga Kerja Kabupaten Purworejo dalam upaya perlindungan pra penempatan pekerja migran Indonesia di luar negeri dari sudut pandang PT Dian Yogya Perdana Cabang Purworejo selaku salah satu pelaksana penempatan pekerja migran Indonesia (P3MI) adalah mulai dari PT Dian Yogya Perdana Cabang Purworejo memproses anak sampai pemberangkatan semuanya di pantau dan Dinas Perindustrian dan Tenaga Kerja Kabupaten Purworejo memberikan izin pemberangkatannya. Dalam hal ini Dinas Perindustrian dan Tenaga Kerja Kabupaten Purworejo juga mengawasi secara langsung dalam pemberangkatan pekerja migran Indonesia yang berasal dari Kabupaten Purworejo untuk ke luar negeri sehingga dimungkinkan pekerja migran Indonesia tersebut terjamin perlindungannya terutama pada pra penempatan. ${ }^{21}$ Menurut Tri Marzuningsih, Dinas Perindustrian dan Tenaga Kerja Kabupaten Purworejo dalam upaya perlindungan pra penempatan pekerja migran Indonesia di luar negeri sangat bagus dalam memberikan pelayanan kepada PT Dian Yogya Perdana Cabang Purworejo dan juga kepada pekerja migran Indonesia. Semua sudah sesuai dengan aturan, seperti sebelum pekerja migran Indonesia diberangkatkan, maka pekerja migran Indonesia tersebut harus di wawancarai terlebih dahulu oleh Dinas Perindustrian dan Tenaga Kerja Kabupaten Purworejo sekaligus membawa dokumen asli yang dibutuhkan. Dokumen tersebut antara lain Kartu Tanda Penduduk, Kartu Keluarga, akta kelahiran, ijazah, surat izin orang tua, dan surat nikah bagi yang sudah menikah. ${ }^{22}$

${ }^{21}$ Yusman Faezal, Wawancara, Staff PT Dian Yogya Perdana Cabang Purworejo, Purworejo 1 April 2019
${ }^{22}$ Tri Marzuningsih, Wawancara, Kepala PT Dian Yogya Perdana Cabang Purworejo, Purworejo 5 April 2019 Administrative Law \& Governance Journal. Volume 3 Issue 1, March 2020 


\section{Administrative Law \& Governance Journal. Volume 2 Issue 1, March 2020 ISSN. 2621-2781 Online}

Terkait dengan wawancara oleh Dinas Perindustrian dan Tenaga Kerja Kabupaten Purworejo dan verifikasi dokumen tersebut adalah suatu bentuk aturan yang memang sudah ditetapkan. Setelah proses wawancara, barulah akan diterbitkan identitas diri pekerja migran Indonesia atau yang biasa disebut kartu tenaga kerja luar negeri (KTKLN) bagi pekerja migran Indonesia yang akan bekerja ke Malaysia dan setiap pekerja migran Indonesia harus mempunyai identitas diri karena identitas diri merupakan pegangan bagi pekerja migran Indonesia saat bekerja di luar negeri. Jadi, peran Dinas Perindustrian dan Tenaga Kerja Kabupaten Purworejo dalam upaya perlindungan pra penempatan pekerja migran Indonesia di luar negeri sangat penting karena perlindungan tersebut menyangkut keamanan dan keselamatan bagi pekerja migran Indonesia ketika bekerja di luar negeri. ${ }^{23}$

Pekerja migran Indonesia menurut Pasal 1 angka (2) Undang-Undang Nomor 18 Tahun 2017 tentang Pelindungan Pekerja Migran Indonesia adalah setiap warga negara Indonesia yang akan, sedang, atau telah melakukan pekerjaan dengan menerima upah di luar wilayah Republik Indonesia. Januarti Ramdhani menyatakan bahwa, peran Dinas Perindustrian dan Tenaga Kerja Kabupaten Purworejo dalam upaya perlindungan pra penempatan pekerja migran Indonesia adalah sangat penting karena Dinas tersebut memberikan informasi ke luar negeri dan memberikan perlindungan agar bekerja ke luar negeri melalui proses yang formal. Pada pra penempatan, pekerja migran Indonesia akan diberikan informasi terkait dengan perusahaan pengguna, tempat tinggal, tindakan yang boleh dilakukan, dan tindakan yang tidak boleh dilakukan. Sehingga pekerja migran Indonesia yang berasal dari Kabupaten Purworejo mendapatkan gambaran terkait hal tersebut dan tidak akan salah dalam mengambil tindakan. ${ }^{24}$

${ }^{23}$ Loc. Cit.

${ }^{24}$ Januarti Ramdhani, Wawancara, Pekerja Migran Indonesia, Purworejo 2 April 2019 
Hambatan yang Dialami Dinas Perindustrian dan Tenaga Kerja Kabupaten Purworejo dalam Upaya Perlindungan Pra Penempatan Pekerja Migran Indonesia di Luar Negeri

Dinas Perindustrian dan Tenaga Kerja Kabupaten Purworejo sebagai unit pelaksana pembangunan di Bidang Ketenagakerjaan Kabupaten Purworejo dalam rangka pelaksanaan tugasnya yaitu meningkatkan perlindungan pra penempatan pekerja migran Indonesia sering menemui berbagai macam hambatan. Hambatan yang dialami Dinas Perindustrian dan Tenaga kerja Kabupaten Purworejo antara lain:

1. Trimo menjelaskan bahwa hambatan yang dialami oleh Dinas Perindustrian dan Tenaga Kerja Kabupaten Purworejo yaitu pekerja migran Indonesia bekerja ke luar negeri adalah alternatif terakhir karena pekerja migran Indonesia tersebut sudah tidak lagi mencari pekerjaan di Indonesia. Kemudian kebanyakan diantara mereka mempunyai hubungan keluarga yang tidak harmonis sehingga pekerja migran Indonesia tersebut lebih memilih bekerja di luar negeri. ${ }^{25}$

2. Menurut Pranoto Puji Hidayanto, hambatan yang dialami oleh Dinas Perindustrian dan Tenaga Kerja Kabupaten Purworejo adalah calon pekerja migran Indonesia jarang terbuka atau tidak mau koordinasi dengan Dinas Perindustrian dan Tenaga Kerja Kabupaten Purworejo jika mengalami masalah saat proses pra penempatan. Sehingga hal tersebut dapat menyulitkan pekerja migran Indonesia itu sendiri dan juga Dinas Perindustrian dan Tenaga Kerja Kabupaten Purworejo jika timbul masalah yang lebih serius. ${ }^{26}$

3. Yakobus Alex Yocom menyatakan bahwa hambatan yang dialami oleh Dinas Perindustrian dan Tenaga Kerja Kabupaten Purworejo adalah calon pekerja

\footnotetext{
${ }^{25}$ Trimo, S.E., Wawancara, Kepala Seksi Penempatan dan Perluasan Tenaga KerjaDinas Perindustrian dan Tenaga Kerja, Purworejo 11 Februari 2019

${ }^{26}$ Pranoto Puji Hidayanto, Wawancara, Pelaksana Bidang Penempatan dan Perluasan Tenaga KerjaDinas Perindustrian dan Tenaga Kerja, Purworejo 13 Februari 2019
} 
migran Indonesia membatalkan proses ke luar negeri dengan alasannya masingmasing. Beberapa alasan tersebut antara lain: ${ }^{27}$

a. Calon pekerja migran Indonesia membatalkan proses ke luar negeri karena mau menikah;

b. Calon pekerja migran Indonesia sakit dan/ atau anaknya sakit-sakitan;

c. Tidak diperbolehkan oleh orangtuanya dan tidak diperbolehkan oleh pasangannya; dan

d. Ada anggota keluarga yang meninggal.

\section{Upaya Dinas Perindustrian dan Tenaga Kerja Kabupaten Purworejo dalam}

\section{Mengatasi Hambatan}

Dinas Perindustrian dan Tenaga Kerja Kabupaten Purworejo dalam melaksanakan perannya mengalami beberapa hambatan. Untuk mengatasi hambatan tersebut, maka Dinas Perindustrian dan Tenaga Kerja Kabupaten Purworejo melakukan berbagai upaya. Upaya-upaya yang dilakukan oleh Dinas Perindustrian dan Tenaga Kerja Kabupaten Purworejo adalah:

1. Menurut Trimo, Dinas Perindustrian dan Tenaga Kerja Kabupaten Purworejo melakukan sosialisasi agar bekerja ke luar negeri dengan tidak terpaksa. Jadi, pekerja migran Indonesia tersebut memang benar-benar berminat untuk bekerja ke luar negeri. Dengan demikian, apapun hal yang akan terjadi ketika berada di luar negeri, pekerja migran Indonesia tersebut sudah siap untuk menghadapi dan menyelesaikannya karena tidak memungkinkan jika pekerja migran Indonesia tersebut menggantungkan diri pada orang lain. Jadi, pekerja migran Indonesia tersebut dituntut untuk dapat menyelesaikan masalahnya sendiri terlebih dahulu. $^{28}$

2. Pranoto Puji Hidayanto menjelaskan bahwa untuk mengatasi hambatan yang dialami oleh Dinas Perindustrian dan Tenaga Kerja Kabupaten Purworejo, maka

\footnotetext{
${ }^{27}$ Yakobus Alex Yocom, Wawancara, Pelaksana Bidang Penempatan dan Perluasan Tenaga KerjaDinas Perindustrian dan Tenaga Kerja, Purworejo 13 Februari 2019

${ }^{28}$ Trimo, S.E., Wawancara, Kepala Seksi Penempatan dan Perluasan Tenaga KerjaDinas Perindustrian dan Tenaga Kerja, Purworejo 11 Februari 2019
} 
upaya yang dilakukan adalah menyarankan agar calon pekerja migran Indonesia untuk selalu terbuka dan berkoordinasi kepada Dinas Perindustrian dan Tenaga Kerja Kabupaten Purworejo jika mengalami masalah saat proses pra penempatan. $^{29}$

3. Yakobus Alex Yocom menyatakan bahwa untuk mengatasi hambatan yang dialami oleh Dinas Perindustrian dan Tenaga Kerja Kabupaten Purworejo, maka upaya yang dilakukan adalah: ${ }^{30}$

a. Menghormati sembari menunggu prosesi pernikahannya selesai;

b. Menunggu sampai calon pekerja migran Indonesia dan/atau anaknya sembuh dari sakitnya;

c. Membujuk agar orangtua dan pasangnnya memperbolehkan untuk bekerja ke luar negeri; dan

d. Menunggu sampai beberapa hari sejak kematian untuk dapat melakukan kembali proses bekerja ke luar negeri.

\section{Kesimpulan}

Berdasarkan hasil penelitian dan pembahasan terhadap pokok permasalahan dalam penulisan hukum ini, maka dapat diambil kesimpulan sebagai berikut: Peran Dinas Perindustrian dan Tenaga Kerja Kabupaten Purworejo dalam upaya perlindungan pra penempatan pekerja migran Indonesia di luar negeri adalah dengan melakukan beberapa program yang berkaitan dengan perlindungan pra penempatan pekerja migran Indonesia tersebut. Program-program tersebut adalah Dinas Perindustrian dan Tenaga Kerja Kabupaten Purworejo mengadakan sosialisasi ke beberapa kecamatan mengenai proses ke luar negeri yang sesuai dengan prosedur, memberikan rekomendasi paspor untuk pekerja migran Indonesia, melakukan wawancara kepada para calon pekerja migran Indonesia, menjelaskan hak dan kewajiban calon pekerja migran/pekerja migran

\footnotetext{
${ }^{29}$ Pranoto Puji Hidayanto, Wawancara, Pelaksana Bidang Penempatan dan Perluasan Tenaga KerjaDinas Perindustrian dan Tenaga Kerja, Purworejo 20 Februari 2019

${ }^{30}$ Yakobus Alex Yocom, Wawancara, Pelaksana Bidang Penempatan dan Perluasan Tenaga KerjaDinas Perindustrian dan Tenaga Kerja, Purworejo 20 Februari 2019
} 
Indonesia, dan melakukan pembinaan terhadap pelaksana penempatan pekerja migran Indonesia (P3MI) yang ada di Kabupaten Purworejo. Semua peran tersebut sudah sesuai dengan aturan yang berlaku.

Hambatan yang dialami oleh Dinas Perindustrian dan Tenaga Kerja Kabupaten Purworejo dalam upaya perlindungan pra penempatan pekerja migran Indonesia di luar negeri antara lain: Menurut Trimo yaitu Pekerja migran Indonesia bekerja ke luar negeri adalah alternatif terkhir dan kebanyakan diantara mereka mempunyai hubungan keluarga yang tidak harmonis; Menurut Pranoto Puji Hidayanto yaitu calon pekerja migran Indonesia jarang terbuka atau tidak mau koordinasi dengan Dinas Perindustrian dan Tenaga Kerja Kabupaten Purworejo jika mengalami masalah saat proses pra penempatan; Menurut Yakobus Alex Yocom yaitu: Calon pekerja migran Indonesia membatalkan proses ke luar negeri karena mau menikah; Calon pekerja migran Indonesia sakit dan/atau anaknya sakit-sakitan; Tidak diperbolehkan oleh orangtuanya dan tidak diperbolehkan oleh pasangannya; dan Ada anggota keluarga yang meninggal.

\section{Daftar Pustaka}

Hadi, Sutrisno, Metodologi Research, UGM

ILO, Employment, Growth, and Basic Needs: A One-World Problem-Report of the DirectorGeneral of ILO to the Tripartit World Employment Conference, Geneve.

Peraturan Bupati Purworejo Nomor 82 Tahun 2016 tentang Kedudukan, Susunan Organisasi, Tugas dan Fungsi, serta Tata Kerja Dinas Perindustrian dan Tenaga Kerja Kabupaten Purworejo.

Peraturan Daerah Kabupaten Purworejo Nomor 4 Tahun 2008 tentang Urusan Pemerintahan Daerah Kabupaten Purworejo; dan

Soemitro, Ronny Hanitijo, Metodologi Penelitian Hukum dan Jurimetri, (Jakarta: Ghalia Indonesia, 1982). 
Sonhaji, Aspek Hukum Penyerahan Sebagian Pekerjaan Kepada Perusahaan Lainnya, Adminitrative Law \& Governance Journal Vol. 1, Edisi 2 Mei 2018.

Suhartoyo, Penguatan Organisasi Buruh / Pekerja Sebagai Sarana Perlindungan Buruh, Administrative Law \& Governance Journal Vol. 1, Edisi 4 November 2018.

Suteki dan Galang Taufani, Metodologi Penelitian Hukum (Filsafat, Teori dan Praktik), Cetakan ke-1, (Depok: PT RajaGrafindo Persada, 2018).

Undang-Undang Dasar Negara Republik Indonesia Tahun 1945;

Undang-Undang Nomor 13 Tahun 2003 tentang Ketenagakerjaan;

Undang-Undang Nomor 18 Tahun 2017 tentang Pelindungan Pekerja Migran Indonesia; 